\title{
Activated Carbon from Renewable Sources: Thermochemical conversion and activation of biomass and carbon residues from biomass gasification
}

\author{
Davide Bergna, Henrik Romar, Sari Tuomikoski, Hanna Runtti, \\ Teija Kangas, Pekka Tynjälä and Ulla Lassi
}

D. Bergna • H. Romar • P. Tynjälä • U. Lassi (*)

Research Unit of Sustainable Chemistry, University of Oulu, P.O. Box 3000, Oulu 90014, Finland; Applied Chemistry Unit, University of Jyvaskyla, Kokkola University Consortium Chydenius, Talonpojankatu 2B, 67100 Kokkola, Finland

e-mail: ulla.lassi@oulu.fi

S. Tuomikoski $\bullet$ H. Runtti • T. Kangas

Research Unit of Sustainable Chemistry, University of Oulu, P.O. Box 3000, Oulu 90014, Finland

\begin{abstract}
Activated carbon is one of the most widely applied adsorbent. As a porous carbon, it is used for the purification of both gaseous and liquid emissions. Activated carbon is prepared from fossil resources, such as coal, or from biomass through (hydro)thermal processing followed by chemical and/or physical activation. Further, some biomass thermal treatment processes, such as biomass gasification, produce carbon residues that can be modified to activated carbon with physical or chemical activation methods. The desired properties of activated carbon, i.e. high specific surface area and porosity, high carbon content and excellent sorption capacity, can be modified and optimized during thermochemical treatment and activation. Those properties, which are shortly considered, are important in different applications for activated carbon.
\end{abstract}

\section{Introduction}

Commercial activated carbon is widely used as an (ad)sorbent in gas and water purification applications. It can be produced by carbonization and activating various materials, such as coal and cellulosic raw materials (Ahmadpour and Do, 1996). Recently, more attention has been paid onto the use of biomass and different types of biowaste as source materials for activated carbon. The production process and quality of activated carbon, for example, affect to the price of the material, but in general, commercial activated carbon is fairly expensive. The preparation of activated carbon is also an energy-consuming process. Therefore other substitutes, such as biomass-based adsorbents, must be investigated (Bart and von Gemmingen 2005; Marsh and Rodríquez-Reinoso 2006; Guo et al. 2009). Among biomasses, waste biomass would be a better alternative because they are abundant, renewable and cheap. The use of biowaste for preparing (ad)sorbents is also very attractive because it helps to decrease the costs of waste disposal and to promote environmental protection. In fact, agricultural wastes and residues (Ioannidou and Zabaniotou, 2007), rice hulls (Teker et al. 1997), palm-tree cobs (Avom et al. 1997), walnut

Manuscript accepted for publication in: "Waste Biomass Management - A Holistic Approach (Eds. L.

Singh and V.C. Kalia), Springer International Publishing, 2017. 
shells (Martínez et al. 2006), corn cobs (Chang et al. 2000), coconut husks (Tan et al. 2008), coconut coir pith (Namasivayam and Sangeetha, 2008), macadamia nutshells (Ahmadpour and Do, 1997), coffee endocarps (Nabais et al. 2008), lignin (Ragan and Megonnell, 2011) and cherry stones (Lussier et al. 1994), for example, have been studied and used to prepare activated carbons with high carbon contents and low price. The Council Directive (1999/31/EC) obliges member states to reduce the amount of biodegradable municipal waste they landfills to $35 \%$ of 1995 levels by 2016, and for some countries, by 2020. In Finland, the landfilling of biodegradable and any other organic waste that contains more than $10 \%$ organic carbon has been forbidden since the beginning of 2016 (Government decree 331/2013). One option is to use these kinds of waste materials as precursors for activated carbon production and to further utilize them in many applications. Due to existing legislation, and to avoid emissions caused by transportation, there is a growing need to study locally available waste materials as precursor materials.

Carbons can be classified as graphitizing and non-graphitizing (Franklin 1951). Activated carbon is derived from non-graphitizable carbons which cannot be converted to crystalline graphite at $2700{ }^{\circ} \mathrm{C}$ and above atmospheric or low pressures. Non-graphitizable carbons exhibit structural disorder but they are never amorphous. (International Committee for Characterization and Terminology of Carbon 1982)Activated carbon typically has a well-developed porous structure. In addition, high internal surface area and good mechanical properties are preferred with activated carbons (Guo et al. 2009). It has a unique porous structure of a three-dimensional network featuring imperfect sections of small-sized graphitic lamellas bonded together extremely closely. The porosity of carbon material is formed when lamellas create a three-dimensional network and then spaces between those lamellas form pores. A majority of carbon atoms have a hexagonal arrangement, with some pentagons and other non-hexagonal rings. (Marsh and Rodríquez-Reinoso 2006)

External and internal structure of activated carbon is useful to distinguish. The external surface of activated carbon is surrounded by the discrete particles but the solid surface of carbon is rarely smooth at the atomic scale. The external surface includes all the prominences and also the surface of those cracks which are wider than they are deep. The internal surface consists of pores, cracks and cavity walls which are deeper than they are wide and which are accessible to the adsorptive. (IUPAC1985)

Basically, preparation of activated carbon is a two-stage process of carbonization and activation. (Ahmadpour and Do 1996) Carbonization takes place under an anoxic atmosphere (usually molecular nitrogen) at temperatures of $450-600^{\circ} \mathrm{C}$. The raw material is decomposed to hydrocarbon compounds and carbonaceous products. In this step, most volatile compounds are eliminated as gaseous products. (Bansal and Meenakshi 2005) The porosity of carbon formed during the carbonization step should be developed further since high enough porosity for most applications are not reached thus far (Marsh and Rodríquez-Reinoso, 2006). Basically, activated carbons can be prepared using either physical or chemical activation. However, the preparation process can consist variable combinations of these two. Physical activation is typically implemented by using carbon dioxide or steam (water vapour) at high temperatures of 700$900^{\circ} \mathrm{C}$. In chemical activation, the most common chemicals are dehydrating agents, such as zinc

Manuscript accepted for publication in: "Waste Biomass Management - A Holistic Approach (Eds. L. Singh and V.C. Kalia), Springer International Publishing, 2017. 
chloride or phosphoric acid. In addition, alkali metal salts, hydroxides and carbonates of potassium and sodium, for example, are widely used. (Srinivasakannan and Zailani, 2004)

Different carbonization methods of biomass and physical and chemical activation are considered. Also, case studies of carbonization and physical/chemical activation of biomass and the direct activation of the previous carbonized carbon residue of biomass gasification is considered. The advantages and drawbacks of each method are given and compared. Finally, the physicochemical properties of activated carbon are considered from the end-user viewpoint, and different utilization applications are presented.

\section{Carbonization of biomass}

Biomass carbonization can be performed by pyrolysis or hydrothermal treatment. After carbonization, activation can be done physically or chemically. Physical activation is typically done in a separate step, but chemical activation can be performed in the same process with carbonization. Different carbonization and activation steps for biomass are presented in Figure 1. In Table 1 reaction conditions and yields for different thermochemical processes are compared. Pyrolysis can be performed at different speeds slow, medium or fast and the reaction condition varies a lot among those. Reaction conditions for hydrothermal carbonization (HTC) and gasification are also presented, and the composition of the product is variable with different thermochemical treatment methods. In this chapter, HTC and dry pyrolysis will be discussed. The chemical or physical activation of carbonized biomass and carbon residue from the biomass gasification process will be discussed in Chapter 3 .

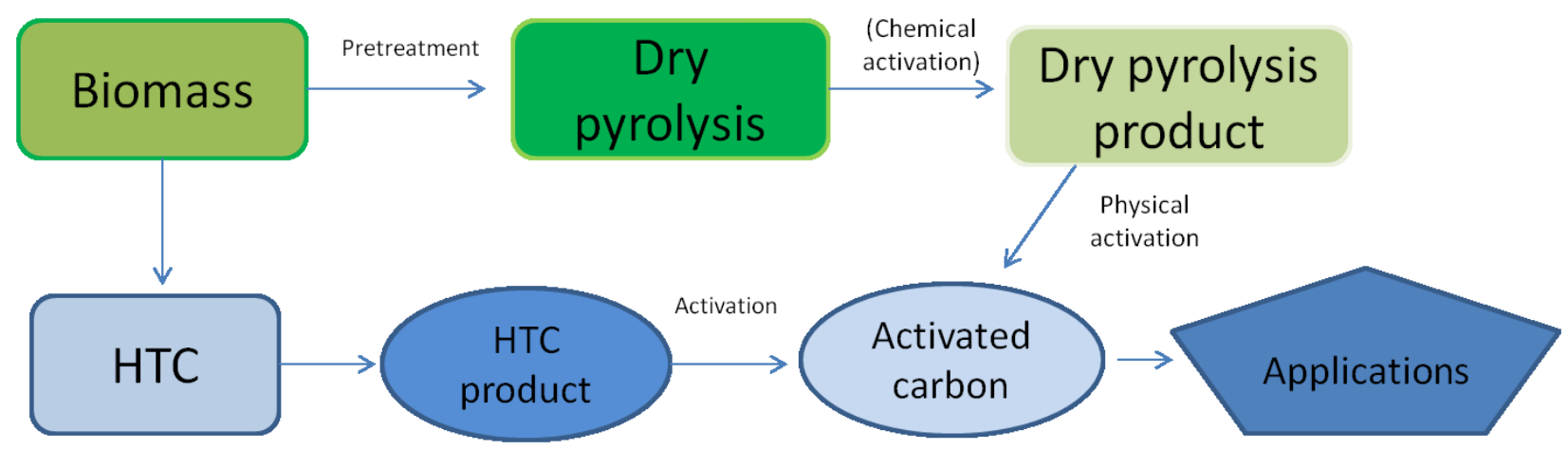

Fig. 1.Possibilities for carbonization and activation of biomass.

Manuscript accepted for publication in: "Waste Biomass Management - A Holistic Approach (Eds. L.

Singh and V.C. Kalia), Springer International Publishing, 2017. 
Table 1. Comparison of reaction conditions and product yields for different thermochemical conversion processes. (Funke and Ziegler, 2010; Libra et al. 2011; Brewer 2012)

\begin{tabular}{|c|c|c|c|c|c|c|}
\hline \multirow[t]{2}{*}{ Process } & \multirow{2}{*}{$\begin{array}{c}\text { Reaction } \\
\text { temperature } \\
\left({ }^{\circ} \mathrm{C}\right)\end{array}$} & \multirow{2}{*}{$\begin{array}{c}\text { Steam } \\
\text { delay time }\end{array}$} & \multirow[t]{2}{*}{ Product } & \multicolumn{3}{|c|}{ Composition of product $(\mathrm{m}-\%)$} \\
\hline & & & & Solid & Liquid & Gas \\
\hline $\begin{array}{l}\text { Pyrolysis, } \\
\text { slow }\end{array}$ & са 400 & $1 \mathrm{~h}$-week & Biochar & 35 & 30 & 35 \\
\hline $\begin{array}{c}\text { Pyrolysis, } \\
\text { medium }\end{array}$ & ca 500 & $10-20 \mathrm{~s}$ & Biochar & 20 & 50 & 30 \\
\hline $\begin{array}{c}\text { Pyrolysis, } \\
\text { fast }\end{array}$ & ca 500 & ca $1 \mathrm{~s}$ & Bio oil & 12 & 75 & 13 \\
\hline Gasification & ca 800 & $10-20 \mathrm{~s}$ & $\begin{array}{c}\text { Synthesis } \\
\text { gas }\end{array}$ & 10 & 5 & 85 \\
\hline HTC & $180-250$ & $\begin{array}{c}\text { No steam } \\
\text { delay, } \\
\text { process } \\
\text { time } 1-12 \mathrm{~h}\end{array}$ & $\begin{array}{c}\text { HTC } \\
\text { carbon }\end{array}$ & $50-80$ & $5-20$ & $2-5$ \\
\hline
\end{tabular}

\subsection{Hydrothermal carbonization}

Hydrothermal carbonization (HTC) is a combination of the dehydration and decarboxylation of a biomass to increase its carbon content. The process of converting biomass to HTC is carried out at elevated temperatures $\left(180-220^{\circ} \mathrm{C}\right)$ in a water suspension at saturated pressures for several hours. With this HTC conversion process, a lignite-like material with the well-defined properties can be prepared from biomass residues. Even high-moisture-content raw material can be utilized in the HTC process. Thus, the HTC process may contribute to a wider range of applications of biomass, not just for energetic purposes. The HTC process has been known for nearly a century, but it still has received only little attention in the current biomass conversion research. In this paper, the HTC process is not given much more attention.

\subsection{Dry pyrolysis}

Dry pyrolysis is the most well-known thermochemical process that produces carbon with a high yield. In addition, dry pyrolysis can produce pyrolysis oil and gas. Dry pyrolysis can be slow or fast, and it is performed without oxygen at temperatures below $500^{\circ} \mathrm{C}$. Biomass used for dry pyrolysis must have quite low water content. Suitable moisture content in slow pyrolysis is $15-$ $20 \%$. Slow pyrolysis produces carbon, distillation products and gases, such as carbon monoxide, carbon dioxide and hydrogen. In fast pyrolysis, biomass is very fine due to very fast heating and the heat transfer condition. It is used mainly for pyrolysis oil production. (Bridgwater 1999; 
Antal et al. 2000; Bridgwater and Peacocke, 2000; Antal and Grønli, 2003; Libra et al. 2011; Fagernäs et al. 2014)

\subsection{Comparison of HTC treatment and dry pyrolysis}

HTC treatment and dry pyrolysis have several advantages and disadvantages. Temperatures are higher in dry pyrolysis as compared with hydrothermal treatment, and raw material has to be dried before pyrolysis, which is not the situation in HTC treatment. Harmful gases, such as PAH compounds and aromatic hydrocarbons, are formed in dry pyrolysis. In addition, tar compounds formation in dry pyrolysis is a problem that does not existing in HTC process. (Fischer and Bieńkowski, 1999; Antal and Grønli, 2003; Sadaka and Negi, 2009; Sevilla et al. 2011)

The disadvantages of HTC treatment are the energy consumption that takes place when the saturated steam (up to $220^{\circ} \mathrm{C}$ ) is being warmed up in the reactor, and the relative high pressure required (25 bars). (Ramke et al. 2009) In dry pyrolysis, energy can be obtained by burning formed synthesis gas. In addition, the separation process for HTC carbon and process water treatment is needed. (Funke and Ziegler, 2010; Libra et al. 2011)

\section{Carbonization and activation of raw materials}

Biomass carbonized by hydrothermal treatment or dry pyrolysis can be activated physically or chemically to produce activated carbon (Ahmadpour and Do, 1996). Typically, the carbonization step is performed first and after that activation can be done. In the case of chemical activation, carbonization and activation can be done in the same step. The porous structure is one of the most important properties of activated carbon. The porosity of carbon material formed during the carbonization step is typically not high enough for most applications which is the reason it is necessary to develop the porosity of the carbon surface further through physical or chemical activation methods (Marsh and Rodríquez-Reinoso, 2006). During the activation process, other specific properties of the carbon surface such as cationic, anionic or neutral surface functional groups, can be developed. The biomass raw material, activation method and conditions play a key role in the characteristics of activated carbon including, for example, the porosity and shapes of pores. (Guo et al. 2009)

In addition to biomass, various carbonaceous by-products and wastes from industry can be used as precursors in activated carbon production. In the future, it is evaluated that the commercial applications for the thermo-chemical or hydrothermal conversion processes of biomass will increase and the suitable utilization applications for formed by-products and wastes should be developed. Waste biomass residue or some other organic residues with high carbon content are formed during these processes. Therefore, some reuse would be needed. By utilizing carbonaceous waste materials as precursors for activated carbon production, only the activation step is needed. In the case study presented in Chapters 3.1.1 and 3.2.1, studied carbon residue was obtained from a biomass gasification pilot plant in which carbon residue is formed as a waste. Carbon residue was used as a raw material for the preparation of adsorbents through chemical and physical activation. Wood chips (pine and spruce) were used as a fuel to the

Manuscript accepted for publication in: "Waste Biomass Management - A Holistic Approach (Eds. L.

Singh and V.C. Kalia), Springer International Publishing, 2017. 
downdraft gasifier $(150 \mathrm{~kW})$. Gasifier was operated at temperature of $1000^{\circ} \mathrm{C}$ and a feeding rate for raw material was $50 \mathrm{~kg} / \mathrm{h}$. (Tuomikoski 2014)

\subsection{Physical activation}

In the activation process, the removal of the carbon atoms from the nanostructure of the precursor accessing and interconnecting the inherent structural porosity occurs (Ragan and Megonnell, 2011). In the physical activation, the carbonized raw material is activated by the physical activating agent. Typically used activating agents are water vapour (steam) or carbon dioxide. Additionally, a mixture of water vapour (steam) and carbon dioxide can be used. The activation temperature varies between $600^{\circ} \mathrm{C}$ and $900^{\circ} \mathrm{C}$. (Guo et al. 2009) Typically the choice of the activation agent and activation time depends on the type of raw material (Guo et al. 2009). 2-6 hours of activation time have been applied for coconut shells, for example.

Physical activation including the carbonization step is typically a two-stage process, and therefore, activation is performed after the carbonization process. A physical activating agent, such as steam, is fed to the precursor material typically at temperatures of between $600{ }^{\circ} \mathrm{C}$ and $800{ }^{\circ} \mathrm{C}$. During this phase the carbon changes physically and in addition to physical changes, its properties change chemically by opening the carbon matrix and changing its functional groups. (Fu et al. 2013) The quantity of water fed depends on the quantity and the material that is processed. Generally, the efficiency of this activation is influenced by the contact between the activating agent and the mass of carbon. Therefore, a rotating activation reactors are preferable during this stage. The entire process has to be realized under an inert atmosphere, typically nitrogen, because the water molecules include hydrogen and oxygen, which generates a potential explosive atmosphere under particular temperature conditions. Steam activation time is also a parameter that has to be optimized because it can influence the structure and the yield of the carbon mass. Generally higher activation times correspond to higher yield loss but also higher porosity, creating micropores. (Chun et al. 2012)

From a chemical point of view, during steam activation, the following compound exists: $\mathrm{O}_{2}$, $\mathrm{CO}_{2}, \mathrm{H}_{2}$ and $\mathrm{H}_{2} \mathrm{O}$. Typical reactions for steam activation are listed in Table 2.

Table 2.Typical reactions that took place under steam activation (Chun et al. 2012)

\begin{tabular}{lll}
\hline Reaction & & \\
\hline Water-gas reaction & $\mathrm{C}+\mathrm{H}_{2} \mathrm{O} \rightarrow \mathrm{CO}+\mathrm{H}_{2}$ & $\Delta \mathrm{H}=131.3 \mathrm{~kJ} / \mathrm{mol}$ \\
$\begin{array}{l}\text { Boudouard reaction } \\
\text { Hydrogasification }\end{array}$ & $\mathrm{C}+\mathrm{CO}_{2} \rightarrow 2 \mathrm{CO}$ & $\Delta \mathrm{H}=171.7 \mathrm{~kJ} / \mathrm{mol}$ \\
$\begin{array}{l}\text { Decomposition reaction of tar } \\
\text { Tar pyrolysis }\end{array}$ & $\mathrm{C}+2 \mathrm{H}_{2} \rightarrow \mathrm{CH}_{4}$ & $\Delta \mathrm{H}=-74.9 \mathrm{~kJ} / \mathrm{mol}$ \\
$\begin{array}{l}\text { Tar steam gasification } \\
\text { Reaction of light gas }\end{array}$ & $\mathrm{Tar} \rightarrow w \mathrm{H}_{2}+x \mathrm{CO}+y \mathrm{CO}_{2}+z \mathrm{C}_{n} \mathrm{H}_{m}$ & \\
$\begin{array}{l}\text { Methanation reaction } \\
\text { Water-gas shift reaction }\end{array}$ & $\mathrm{Tar}+v \mathrm{H}_{2} \mathrm{O} \rightarrow x \mathrm{CO}+y \mathrm{H}_{2}$ & \\
Steam reforming & $\mathrm{CO}+3 \mathrm{H}_{2} \leftrightarrow \mathrm{CH}_{4}+\mathrm{H}_{2} \mathrm{O}$ & $\Delta \mathrm{H}=-206.2 \mathrm{~kJ} / \mathrm{mol}$ \\
& $\mathrm{CO}+\mathrm{H}_{2} \mathrm{O} \leftrightarrow \mathrm{CO}_{2}+\mathrm{H}_{2}$ & $\Delta \mathrm{H}=-41.1 \mathrm{~kJ} / \mathrm{mol}$ \\
& $\mathrm{C}_{n} \mathrm{H}_{m}+n \mathrm{H}_{2} \mathrm{O}=n \mathrm{CO}+(n+m / 2) \mathrm{H}_{2}$ & \\
& $\mathrm{C}_{n} \mathrm{H}_{m}$ is the light hydrocarbon &
\end{tabular}

Manuscript accepted for publication in: "Waste Biomass Management - A Holistic Approach (Eds. L.

Singh and V.C. Kalia), Springer International Publishing, 2017. 


\subsubsection{Physical activation of carbon residue from biomass gasification}

In the case study of Tuomikoski (2014), the precursor material for physical activation was carbon residue, which is formed as a waste material in the biomass gasification process. Carbonization step was not done in the presented case study because it was assumed to have already taken place during the thermal gasification process of biomass, in which precursor material was formed as a waste material. Physical activation was carried out by using carbon monoxide $(\mathrm{CO})$ and carbon dioxide $\left(\mathrm{CO}_{2}\right)$ as physical activating agents. Additionally, reference samples were prepared by thermal treatment without any activating agent under a nitrogen atmosphere. The temperature and duration of activation were the two parameters investigated in addition to the activating agent. Temperatures of $600{ }^{\circ} \mathrm{C}$ and $800{ }^{\circ} \mathrm{C}$ were used. The duration of activation was one or three hours. The activation conditions during physico-chemical activation are presented in detail in Kilpimaa et al. (2015). The success of the activation was evaluated by characterization of the produced material. The specific surface area and pore volume, for example, from the produced adsorbents were measured. FESEM image of physically activated (by carbon dioxide) carbon residue is presented in Figure 2.

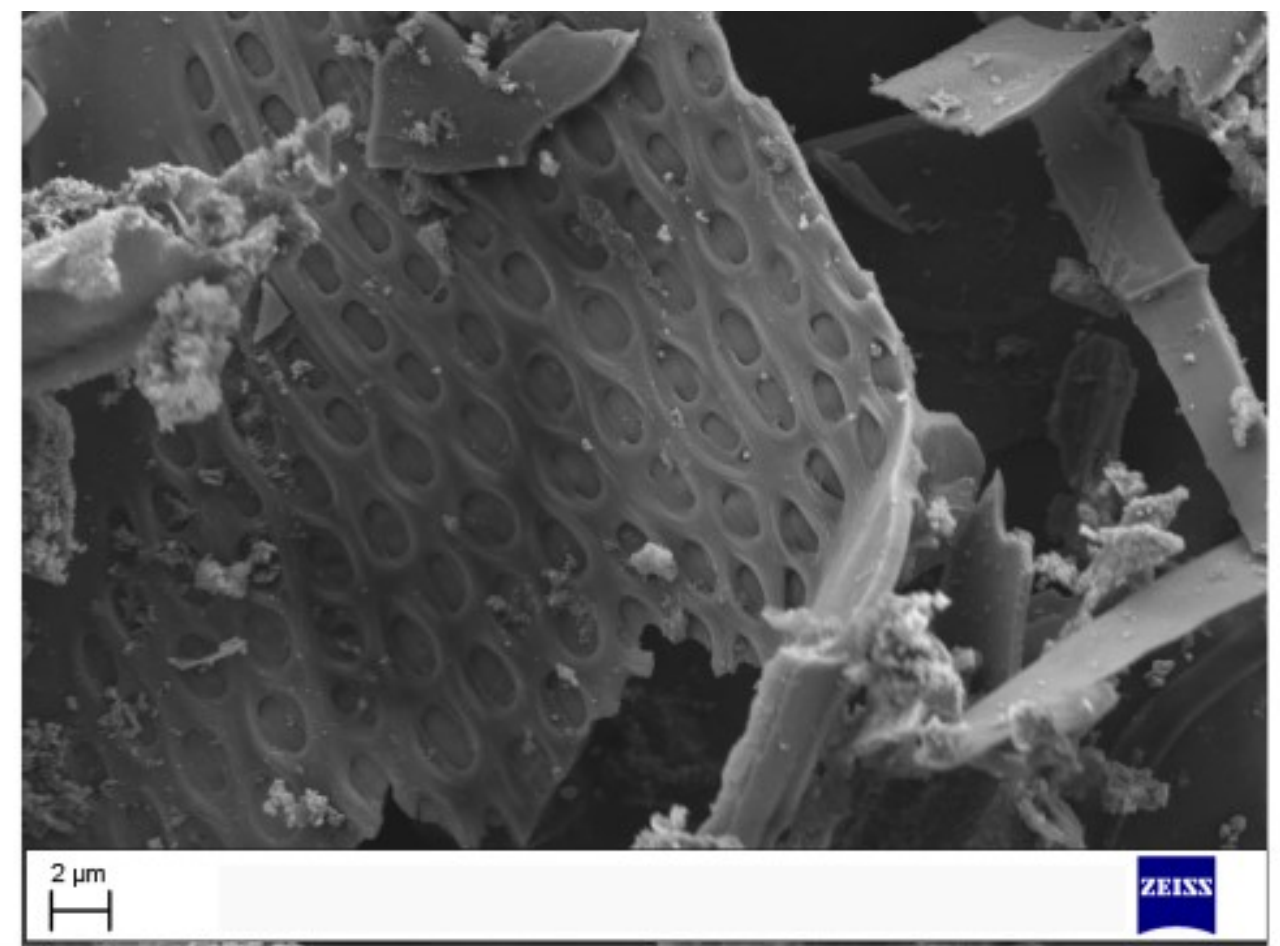

Fig. 2.FESEM-image of the carbon residue sample which was activated with carbon dioxide $\left(\mathrm{CO}_{2}\right)$, magnification $\mathrm{x8000}$. 


\subsubsection{Carbonization and physical activation of virgin lignocellulosic biomass}

In the other case study, biomass was carbonized and activated physically (Bergna et al. 2016). In this study, three sawdust samples originating from birch, spruce and pine were used as precursors for activated carbon production. Prior to carbonization/activation, the precursors were dried at $105{ }^{\circ} \mathrm{C}$ overnight. The sawdusts were carbonized and activated in a one step process consisting of carbonization with a temperature ramp from an ambient temperature to $800{ }^{\circ} \mathrm{C}$. During this step, the reactor, a rotating quartz tube fit into a tubular oven, was flushed with nitrogen. At $800{ }^{\circ} \mathrm{C}$, the samples were activated physically by steam for a fixed period of time by passing steam through the reactor using nitrogen as the carrier gas. The specific surface area was increased notably during the carbonization and activation steps. FESEM images of the precursors and the activated carbons are presented in Figure 3, in which a pore structure can be observed.

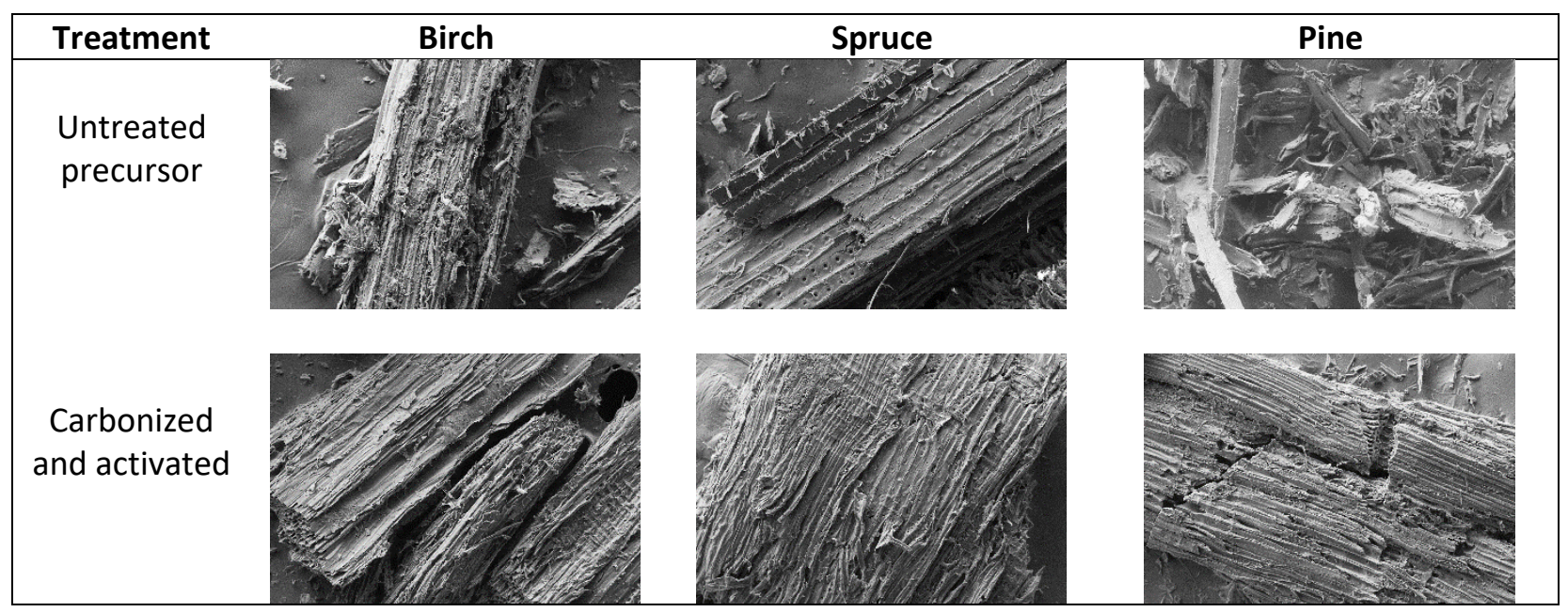

Fig 3.FESEM image obtained before and after carbonization and physical activation

\subsection{Chemical activation}

Chemical activation can be considered a single-step process in which the carbonization of raw material and activation are done simultaneously. Substances which contain alkali and alkaline earth metal and some general acids are typically used as a chemical activating agent such as $\mathrm{KOH}, \mathrm{NaOH}, \mathrm{ZnCl}_{2}$ and $\mathrm{H}_{3} \mathrm{PO}_{4}$. (Ahmadpour and Do, 1996) Chemicals during activation step can act as a dehydrating agent (for example $\mathrm{ZnCl}_{2}$ and $\mathrm{H}_{3} \mathrm{PO}_{4}$ ) and that types of chemical are commonly used for the activation of especially lignocellulosic materials. Alkali hydroxides are typically used chemical activating agents for the activation of coal or chars. (Srinivasakannan and Zailani, 2004)

\subsubsection{Chemical activation of the carbon residue formed in biomass gasification}

In the case study of Tuomikoski (2014), the carbon residue from the biomass gasification process was chemically activated to produce suitable water purification material. In the case study, a wet impregnation method for the chemical activation was used. Carbon residue pretreatment is Manuscript accepted for publication in: "Waste Biomass Management - A Holistic Approach (Eds. L. Singh and V.C. Kalia), Springer International Publishing, 2017. 
described in detail in Kilpimaa et al. (2014). After the pretreatment, the sample and the chemical were mixed and the used contact time was five minutes. Chemicals used for the chemical activation of the carbon residue were $0.1 \mathrm{M} \mathrm{HCl}, 0.1 \mathrm{M} \mathrm{H}_{2} \mathrm{SO}_{4}, 5 \mathrm{M} \mathrm{ZnCl}_{2}, 5 \mathrm{M} \mathrm{KOH}, \mathrm{HCl}$ or $\mathrm{HNO}_{3}$. The used liquid-to-solid ratio $\mathrm{L} / \mathrm{S}$ between chemical activating agent and carbon residue was $10(\mathrm{w} / \mathrm{w})$. After that, the mixture of the carbon residue and chemical activating agent was dried at $110{ }^{\circ} \mathrm{C}$ overnight. Activation was done at $500{ }^{\circ} \mathrm{C}$ and the duration of activation was one hour. The products were washed sequentially with $0.5 \mathrm{M} \mathrm{HCl}$ and used time for that was 10 minutes by using L/S (liquid-to-solid ratio) of 10. Additionally, hot distilled water and finally cold distilled water were used in the washing stage. This step was done to remove any remaining organic and inorganic residues. Before use, products were dried at $110{ }^{\circ} \mathrm{C}$ overnight, crushed and sieved to obtain particle size below $150 \mu \mathrm{m}$.

The surface area and porosity of the carbonaceous material are known to depend on the variables of the preparation process. For that reason the L/S-ratio of the carbon residue and chemical activating agent, the concentration of the impregnation solution and the activation time were optimized. In the case study (Tuomikoski 2014), the highest specific surface area for the carbon residue sample was obtained by using a $5 \mathrm{M}$ zinc chloride solution with $\mathrm{L} / \mathrm{S}$-ratio of 10 and activation time of one hour in the chemical activation at $500{ }^{\circ} \mathrm{C}$. In the Figure 4, FESEM images for chemically activated $\left(\mathrm{ZnCl}_{2}\right)$ carbon residue, commercial activated carbon and carbon residue from biomass gasification are presented as a reference. These images illustrate the crystals on the surfaces of the adsorbents and the porous structure of the adsorbents. Activated carbon residue and activated carbon seem to be clearly more porous materials than carbon residue. The measured values of specific surface areas presented in Table 4agree with this argument. (Kilpimaa et al. 2012, 2014)

Manuscript accepted for publication in: "Waste Biomass Management - A Holistic Approach (Eds. L. Singh and V.C. Kalia), Springer International Publishing, 2017. 


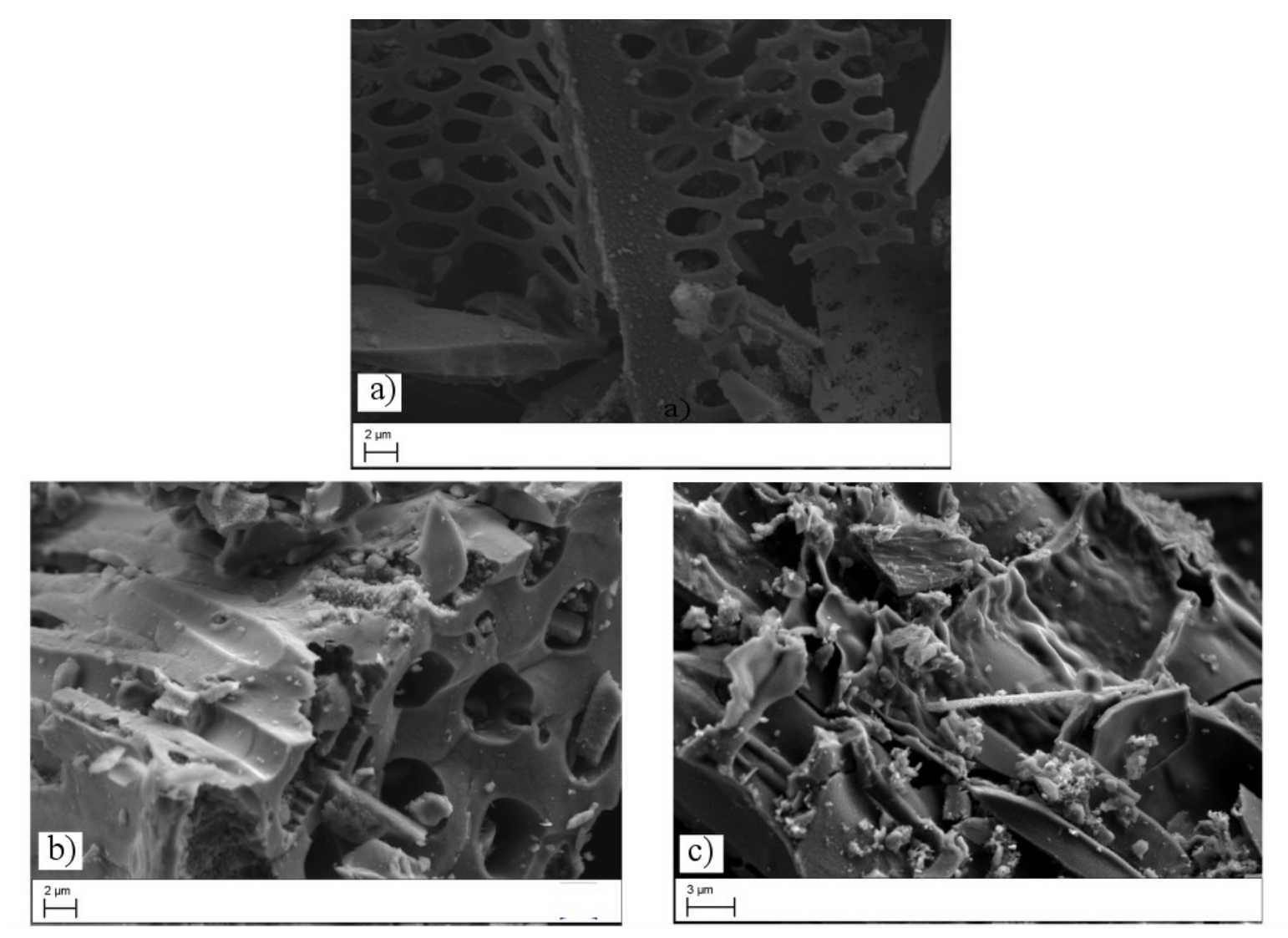

Fig. 4. FESEM images for a) chemically $\left(\mathrm{ZnCl}_{2}\right)$ activated carbon residue, b) commercial activated carbon and c) carbon residue without any activation, magnification $\mathbf{x} 7000$.

\subsection{Comparison of physical and chemical activation}

There are several advantages and disadvantages in the physical and chemical activation methods. When comparing chemical activation to physical one, the main advantages in the chemical activation comparing are lower activation temperature, shorter activation time and typically, the higher porosity of produced carbons are obtained. The main disadvantage of the chemical activation is the secondary pollution which is formed from the activation chemicals. Additionally, chemical consumption and price must be taken into account in the discussion of advantages and disadvantages. A washing stage is required in the chemical activation method and therefore, physical activation could be more environmentally friendly and effective method to produce an adsorbent from biowaste material. (Marsh and Rodríquez-Reinoso, 2006)

\section{Physico-chemical properties of activated carbon}

The properties of activated carbons depend on a number of factors, including the biomass used, carbonization conditions, activation conditions and the physical or chemical activating agents used. According to the methods published by the European council of chemical manufacturers' federations "Test methods for activated carbon" there are some suggestions that which parameters should be determined from the activated carbons. These parameters include bulk Manuscript accepted for publication in: "Waste Biomass Management - A Holistic Approach (Eds. L. Singh and V.C. Kalia), Springer International Publishing, 2017. 
properties measurement such as density $\left(\mathrm{kg} / \mathrm{m}^{3}\right)$, water content and mechanical strength and in addition, adsorption properties should be determined. The widely used application for activated carbon is use as an adsorbent and therefore, adsorption tests are typically done. Those are tests that include both liquid and gas phase adsorption. (European council of chemical manufacturers' federations 1986)

Density measurements are divided into bulk density, absolute density and particle density. Bulk density is defined as "mass of a unit volume of the sample in air, including both the pore system and voids between the particles". The bulk density depends on parameters such as the shapes, sizes and densities of the individual particles. The determinations is performed by transferring a representative portion of the sample into a graduated measuring cylinder (about $100 \mathrm{~mL}$ ), recording the volume and measuring the weight of the sample. Samples can be used as received or dried prior to measurement. Bulk density $\left(\mathrm{kg} / \mathrm{m}^{3}\right)$ is calculated from Equation (1):

$$
\mathrm{D}_{\mathrm{b}}=1000 * \mathrm{M} / \mathrm{V}
$$

where $\mathrm{M}$ is the mass of the sample in grams and $\mathrm{V}$ is the volume of the sample in $\mathrm{mL}$.

Absolute density (or helium density) is defined as "the mass of a unit volume of the carbon skeleton that is inaccessible to helium". Measurements are made with commercial helium pycnometers, according to the instructions of the manufacturer. Prior to analysis, the samples are dried at $150^{\circ} \mathrm{C}$ to a constant weight. (European council of chemical manufacturers' federations 1986)

Particle density or Hg-density is defined as "the mass of a unit volume of the carbon particles, including its pore system". Measurements are made using a pycnometer constructed to operate under vacuum using mercury as medium. (European council of chemical manufacturers' federations 1986)

Water content or moisture content tests can be performed if water is known to be the only volatile material which presents in the carbon. Xylene distillation is typically used for heatsensitive carbons, or if water-insoluble material is present in the carbon. This test is performed by drying a sample (1-2 grams for powdered carbon, or 5-10 grams for granular carbon) at 145$155^{\circ} \mathrm{C}$ to a constant weight. (European council of chemical manufacturers' federations 1986)

In addition, the success of physical or chemical activation can be evaluated by characterization of the produced material, i.e. the specific surface area, the pore volume and the pore size were measured. By measuring the carbon content, the burn-off of the material can be measured, and the success of the carbonization can be evaluated. Adsorptive capacity results from the porous network that exists within the grains of activated carbon. The internal surface area in addition to the pore volume are notably greater comparing with the external surface area and the volume of the grains themselves (Ragan and Megonnell, 2011). Commercial activated carbon exhibits a high internal surface area of $1000 \mathrm{~m}^{2} / \mathrm{g}$ or higher, and large internal pore volume $\left(0.3-3 \mathrm{~cm}^{3} / \mathrm{g}\right)$. Porosity within adsorbents has been classified by IUPAC (International Union of Pure and Applied Chemistry) (1972) according to the widths of the pores as follows: macropores (access pores, $1000 \mathrm{~nm}$ down to $50 \mathrm{~nm}$ in width), mesopores (transport pores, between $50 \mathrm{~nm}-2 \mathrm{~nm}$ in

Manuscript accepted for publication in: "Waste Biomass Management - A Holistic Approach (Eds. L.

Singh and V.C. Kalia), Springer International Publishing, 2017. 
width), and micropores (smallest pores with highest adsorption energy, $<2 \mathrm{~nm}$ wide). The porosity of typical activated carbon is presented in Table 3. A summary of properties for adsorbents in the case study of Tuomikoski (2014) is presented in Table 4.

Table 3. Porosity in typical activated carbon (Ruthven 1984; Marsh and Rodríquez-Reinoso, 2006)

\begin{tabular}{llll}
\hline Parameter & Micropore & Mesopore & Macropore \\
\hline Pore diameter $(\mathrm{nm})$ & $<2$ & $2-50$ & $>50$ \\
Pore volume $\left(\mathrm{cm}^{3} / \mathrm{g}\right)$ & $0.15-0.5$ & $0.02-0.1$ & $0.2-0.5$ \\
Surface area $\left(\mathrm{m}^{2} / \mathrm{g}\right)$ & $100-1500$ & $10-100$ & $0.5-2$ \\
\hline
\end{tabular}

Table 4. Summary of the properties for studied adsorbents (Tuomikoski 2014).

\begin{tabular}{lllll}
\hline Parameter & CR & PACR & CACR & AC \\
\hline Carbon content $(\%)$ & 69.5 & 52.1 & 61.8 & 91.9 \\
Surface area $\left(\mathrm{m}^{2} / \mathrm{g}\right)$ & 52.4 & 590 & 285 & 786 \\
Pore diameter $(\mathrm{nm})$ & 8.16 & 3.44 & 3.94 & 2.21 \\
Pore volume $\left(\mathrm{cm}^{3} / \mathrm{g}\right)$ & 0.107 & 0.335 & 0.26 & 0.435 \\
\hline CR=Carbon residue, & PACR=Physically & (by carbon dioxide) activated & carbon & residue, \\
CACR=Chemically $\left(\mathrm{ZnCl}_{2}\right)$ activated carbon residue, AC=Activated carbon & &
\end{tabular}

\section{Utilization application as an adsorbent}

Produced activated carbon has been applied in water purification applications for the removal of several impurities such as organics, metal cations and anions from wastewaters. The high adsorption capacity of activated carbon is based on the strong interaction i.e. the attractive forces exists between the atoms in the walls of the nanopores and the contaminant molecules which are to be removed at the atomic level. The adsorptive capacity of activated carbon results from the complex, three-dimensional, interconnected porous network that exists within the activated carbon grains (Ragan and Megonnell, 2011). Although the adsorption capacity is mainly determined by the microporous structure, the surface chemistry of the carbon adsorbent also plays an important role in determining its adsorption properties and behavior. Typically, surface of activated carbon is nonpolar and therefore, it favors the adsorption of nonpolar molecules by non-specific mechanisms. (Moreno-Castilla 2004; Marsh and Rodríquez-Reinoso, 2006) The polarity of the surface can be altered and the adsorption of polar molecules increased by an adequate modification. The surface chemistry therefore depends on the heteroatom contents. On the surface, chemisorbed oxygen, hydrogen etc. may exist and oxygen-containing functional groups have great importance for the surface characteristics because they determine the surface charge and the hydrophobicity of activated carbon. The surface charge can be determined by titration or by using electrokinetic methods. The first method provides a measure of the total surface charge, whereas the latter primarily measures the surface charge at the more external surface of the particles. The point of zero charge $\left(\mathrm{pH}_{\mathrm{ZPC}}\right)$ is the $\mathrm{pH}$ in which the total surface charge is zero, and the isoelectric point $\left(\mathrm{pH}_{\mathrm{IEP}}\right)$ describes $\mathrm{pH}$ in which the $\mathrm{pH}$ of the external surface is zero. (Rodríquez-Reinoso and Molina-Sabio, 1998; Marsh and Rodríquez-Reinoso, 2006) The $\mathrm{pH}_{\mathrm{ZPC}}$ values for adsorbents in case study of Tuomikoski (2014) are presented in Table 5. In the $\mathrm{pH}$ values above $\mathrm{pH}_{\mathrm{ZPC}}$, the adsorbent is favoured to remove anions and in the $\mathrm{pH}$ values measured below $\mathrm{pH}_{\mathrm{ZPC}}$, the adsorbent removes cations.

Manuscript accepted for publication in: "Waste Biomass Management - A Holistic Approach (Eds. L. Singh and V.C. Kalia), Springer International Publishing, 2017. 
Table 5. Measured point of zero charge values for the adsorbents studied in Tuomikoski 2014.

\begin{tabular}{ll}
\hline Sample & $\mathbf{p H z P C}$ \\
\hline CACR & 4 \\
PACR & 3 \\
CR & 2.1 \\
AC & 2.1 \\
\hline
\end{tabular}

$\mathrm{CACR}=$ Chemically $\left(\mathrm{ZnCl}_{2}\right)$ activated carbon residue, $\mathrm{PACR}=$ Physically $\left(\mathrm{CO}_{2}\right)$ activated carbon residue, $\mathrm{CR}=$ Carbon residue, $\mathrm{AC}=$ Activated carbon

When evaluating utilization potential as an adsorbent, adsorption isotherms are vital to calculate. An isoterm is constructed by plotting the residual concentration of the test substance against the mass of carbon. Adsorption isotherms are used for designing an adsorption system since they represent the amount of species adsorbed versus the amount of species left in the solution phase at equilibrium. Isotherms give information about the nature of the adsorption and adsorption capacity $\left(\mathrm{q}_{\mathrm{m}}\right)$ can be calculated. Capacity makes different adsorbents and their adsorption capacities comparable because it is not dependent on conditions in which adsorption experiments have been done. Adsorption isotherms furthermore give information about a larger scale adsorption process.

The most commonly used adsorption isotherm is the Langmuir model (Langmuir 1918). The following assumption are made in the Langmuir isotherm model: 1) there are only one kind of adsorption sites on the surface, 2) the energy of the adsorption is independent of how many of the surrounding sites are occupied, 3) maximum adsorbate coverage is one monolayer, 4) all adsorption occurs through the same mechanism. The linear form of the Langmuir isotherm model is given by Equation (2), as follows:

$$
\frac{1}{q_{e}}=\frac{1}{q_{m}}+\frac{1}{q_{m} b C_{e}}
$$

where $\mathrm{q}_{\mathrm{e}}(\mathrm{mg} / \mathrm{g})$ is the adsorption amount, $\mathrm{C}_{\mathrm{e}}(\mathrm{mg} / \mathrm{L})$ is the equilibrium concentration and $\mathrm{q}_{\mathrm{m}}$ $(\mathrm{mg} / \mathrm{g})$ and $\mathrm{b}(\mathrm{L} / \mathrm{mg})$ are the Langmuir constants which are related to the adsorption capacity and adsorption energy, respectively. Furthermore, the constants of Langmuir model were obtained from the linear plots of $1 / \mathrm{q}_{\mathrm{e}}$ versus $1 / \mathrm{C}_{\mathrm{e}}$. In addition to the Langmuir model, there are several other isotherm models, such as the bi-Langmuir model, Temkin, Freundlich model, D-R model and Sips model, and every model has its own characteristics and hypotheses. (Freundlich 1906, Temkin and Pyzhev, 1940; Karthikeyan et al. 2004; Repo et al. 2009;Zheng et al. 2009; Repo et al. 2011;Roosta et al. 2014a,2014b, 2014c)

In addition to the adsorption isotherm model, the rate of adsorption is important to know. The kinetic studies where the progress of the adsorption processes is followed in the function of time provide useful information about the efficiency of adsorption. Kinetic results are also crucial when the feasibility of the process for large scale applications is considered. Both Pseudo-first-

Manuscript accepted for publication in: "Waste Biomass Management - A Holistic Approach (Eds. L.

Singh and V.C. Kalia), Springer International Publishing, 2017. 
order and pseudo-second-order kinetic models are most commonly utilized to identify the kinetics of the adsorption process (Lagergren 1898; Ho and McKay, 1999). The equation of Lagergren (Lagergren 1898) is widely used to describe the adsorption of liquid phase compounds to the solid adsorbate surface. Most often the modelling has been accomplished using the linear form of pseudo-first-order rate expression which is given as follows (Bhatnagar et al. 2010b):

$$
\log \left(q_{e}-q_{t}\right)=\log q_{e}-\frac{k_{f}}{2.303} t
$$

where $\mathrm{q}_{\mathrm{e}}$ and $\mathrm{q}_{\mathrm{t}}$ are the amounts of impurities adsorbed $(\mathrm{mg} / \mathrm{g})$ at equilibrium and at time $\mathrm{t}$, respectively. The rate constants in the pseudo-first-order equation is marked as $\mathrm{k}_{\mathrm{f}}\left[\mathrm{min}^{-1}\right]$.

Pseudo-second-order process can be expressed in a linear form (Bhatnagar et al. 2010b):

$$
\frac{t}{q_{t}}=\frac{1}{k_{s} q_{e}{ }^{2}}+\frac{1}{q_{e}} t
$$

where $\mathrm{k}_{\mathrm{s}}\left[\mathrm{g} \mathrm{mg}^{-1} \mathrm{~min}^{-1}\right]$ is the rate constant of pseudo-second-order kinetics.

\subsection{Adsorption experiments over carbon-based adsorbents}

\subsubsection{Standard method}

In the adsorption tests for liquids, the activated carbon comes into contact with a solution containing a specific test substance. The contact time has to be long enough for equilibrium formation. A number of test substances can be used; for instance phenol, iodine and methylene blue are typically used model substances. If the activated carbon is to be used for pharmaceutical purposes phenazone adsorption is used. In addition to standard methods, specific test solutions for the applications of customers can be used. A summary of different adsorbents is presented in Table 6. (European council of chemical manufacturers' federations 1986)

In addition to liquid phase experiments, activated carbon works as an adsorbent also in gas phase adsorption. The adsorption properties of gaseous compounds are tested by feeding the gas at a known concentration and velocity through a bed of activated carbon and registering the breakthrough volume, i.e. the gas volume needed to saturate all binding places of the carbon. (European council of chemical manufacturers' federations 1986)

Manuscript accepted for publication in: "Waste Biomass Management - A Holistic Approach (Eds. L. Singh and V.C. Kalia), Springer International Publishing, 2017. 
Table 6. Summary of test substances for evaluating of adsorption capacity in liquid phase and gas phase (European council of chemical manufacturers' federations 1986).

\begin{tabular}{lll}
\hline Liquid/gas phase & Property tested & Adsorbent \\
\hline Liquid phase & Mesopores & Methylene Blue \\
Liquid phase & Micropores & Iodine \\
Liquid phase & Pharmaceutical use & Phenazone \\
Liquid phase & & $\begin{array}{l}\text { Application specific } \\
\text { compounds }\end{array}$ \\
Gas phase & & Carbon tetrachloride $(\mathrm{g})$ \\
Gas phase & Gas binding capacity & Application specific \\
& Gas binding capacity & compounds \\
\hline
\end{tabular}

\subsubsection{Case study}

In the studies of Runtti et al. (2014) and Kilpimaa et al. (2014, 2015), laboratory experiments were carried out to examine the adsorption capacity for the produced adsorbents. During experiments, the effects of different variables such as the effect of initial $\mathrm{pH}$, initial concentration of adsorbate solution and adsorption time on the adsorption efficiency of phosphates, nitrates, iron(II), copper(II) and nickel(II) were studied. Used adsorbents were carbon residue from the wood gasification process, carbon residue which was activated physically or chemically and commercial activated carbon provided by Norit. The properties of adsorbents were previously presented in tables 4 and 5. The experiments were done using a batch type of process and the effect of the initial $\mathrm{pH}$ was studied in the $\mathrm{pH}$ range of 4-8. The effect of the initial solution concentration was studied with a concentration range of $25-125 \mathrm{mg} / \mathrm{L}$ (chemically activated samples) or concentrations of $10-140 \mathrm{mg} / \mathrm{L}$ (physically activated samples) and experiments were done at optimum $\mathrm{pH}$ determined in the previous step. The model solution was prepared by adding solid $\mathrm{KH}_{2} \mathrm{PO}_{4}$ or $\mathrm{NaNO}_{3}$ to distilled water in the case of phosphate and nitrate respectively. Model metal solutions prepared from iron sulphate $\left(\mathrm{FeSO}_{4} \cdot 7 \mathrm{H}_{2} \mathrm{O}\right)$, copper sulphate $\left(\mathrm{CuSO}_{4} \cdot 5 \mathrm{H}_{2} \mathrm{O}\right)$ and nickel sulphate $\left(\mathrm{NiSO}_{4} \cdot 6 \mathrm{H}_{2} \mathrm{O}\right)$. In the all adsorption experiments, the adsorbent dose used was $5 \mathrm{~g} / \mathrm{L}$.

In the studies in which the optimum initial $\mathrm{pH}$ and effect of initial concentrations were determined, a solution of adsorbate and adsorbent was mixed. After that, the $\mathrm{pH}$ of the mixture was adjusted by $\mathrm{HCl}$ or $\mathrm{NaOH}$. $\mathrm{pH}$ was adjusted after adding the adsorbent to adsorbate solution to ensure the correct $\mathrm{pH}$ of the adsorbent-adsorbate mixture due to the fact that the carbon residue from the gasification process is clearly alkaline $(\mathrm{pH} \approx 9)$ which increases the $\mathrm{pH}$. In addition, the carbon residue has some buffer capacity which means that material is able to retain an almost constant $\mathrm{pH}$ when a small amount of acid is added to the solution, and therefore, it possesses ions that have the ability to neutralise the added hydrogen ions. These ions are similar to hydrogen carbonates, carbonates, and hydroxides. (Kilpimaa et al. 2011, 2013) The solution was shaken at room temperature for 24 hours.

Further in the studies of Kilpimaa et al. $(2014,2015)$ and Runtti et al. (2014), the effect of the adsorption time was studied. These experiments were done by using optimum initial $\mathrm{pH}$ and initial concentration of adsorbate. The rate of adsorption was determined with different time

Manuscript accepted for publication in: "Waste Biomass Management - A Holistic Approach (Eds. L.

Singh and V.C. Kalia), Springer International Publishing, 2017. 
intervals of $1 \mathrm{~min}$ - $24 \mathrm{~h}$. Before analysis, all samples, including the initial samples, were filtered through a $0.45 \mu \mathrm{m}$ filter. The phosphate and nitrate concentrations were analyzed by ion chromatography (Metrohm 761 Compact IC). Heavy metals were determined by an atomic absorption spectrometer (AAS) (PerkinElmer AAnalyst 200) whose absorption wavelengths were found to be $\mathrm{Fe}^{2+}(248.3 \mathrm{~nm}), \mathrm{Cu}^{2+}(324.7 \mathrm{~nm})$ and $\mathrm{Ni}^{2+}(232.0 \mathrm{~nm})$, respectively.

The amount of ions adsorbed $\left(\mathrm{q}_{\mathrm{e}}\right.$ in $\left.\mathrm{mg} / \mathrm{g}\right)$ was determined as follows:

$$
q_{e}=\frac{C_{0}-C_{e}}{m} \cdot V
$$

where $\mathrm{C}_{0}$ and $\mathrm{C}_{\mathrm{e}}$ are the initial and equilibrium concentrations of impurity ion in a solution $(\mathrm{mg} / \mathrm{L})$, respectively, $\mathrm{V}$ is the volume of solution $(\mathrm{L})$ and $\mathrm{m}$ is the mass of the adsorbent $(\mathrm{g})$. (Bhatnagar et al. 2010a, 2010b).

\subsubsection{Literature survey}

Commercial activated carbon and carbon from biomass have been widely applied as adsorbent for water purification. Table 7 lists some of the known references for experimental adsorption capacities ( $\left.\mathrm{q}_{\mathrm{m}, \mathrm{exp}}\right)$ and Langmuir adsorption capacities $\left(\mathrm{q}_{\mathrm{m}}\right)$ for different adsorbents and adsorbates. Results indicate that adsorption capacities vary a lot between activated carbons produced from different raw materials with different activation methods.

Table 7.Experimental sorption capacities $\left(\mathrm{q}_{\mathrm{m}, \exp }\right)$ and Langmuir adsorption capacity for different adsorbents and adsorbates.

\begin{tabular}{|c|c|c|c|c|}
\hline Adsorbate & Adsorbent & $q_{\mathrm{m}, \exp }(\mathrm{mg} / \mathrm{g})$ & $q_{m}(\mathrm{mg} / \mathrm{g})$ & References \\
\hline \multirow[t]{7}{*}{ Phosphate } & $\begin{array}{l}\text { Chemically } \\
\text { activated carbon } \\
\text { residue }\end{array}$ & 20.5 & 14.3 & Kilpimaa et al. 2014 \\
\hline & Iron oxide tailings & - & 8.21 & Zeng et al. 2004 \\
\hline & $\begin{array}{l}\text { Physically }\left(\mathrm{CO}_{2}\right) \\
\text { activated carbon } \\
\text { residue }\end{array}$ & & 30.2 & Kilpimaa et al. 2015 \\
\hline & Goethite & - & 6.42 & $\begin{array}{l}\text { Borggaard et al. } \\
2005\end{array}$ \\
\hline & $\begin{array}{l}\text { Commercial } \\
\text { activated carbon }\end{array}$ & 8.7 & 6.44 & Kilpimaa et al. 2014 \\
\hline & $\begin{array}{l}\text { Iron-hydroxide } \\
\text { modified eggshell }\end{array}$ & - & 14.5 & $\begin{array}{l}\text { Mezenner and } \\
\text { Bensmaili, } 2009\end{array}$ \\
\hline & $\begin{array}{l}\text { Natural zeolite with } \\
\mathrm{Na}\end{array}$ & - & 2.19 & Wu et al. 2006 \\
\hline \multirow[t]{4}{*}{ Nitrate } & $\begin{array}{l}\text { Chemically } \\
\text { activated carbon } \\
\text { residue }\end{array}$ & 7.97 & 3.06 & Kilpimaa et al. 2014 \\
\hline & $\begin{array}{l}\text { Physically }\left(\mathrm{CO}_{2}\right) \\
\text { activated carbon } \\
\text { residue }\end{array}$ & & 11.2 & Kilpimaa et al. 2015 \\
\hline & $\begin{array}{l}\text { Commercial } \\
\text { activated carbon }\end{array}$ & 14.6 & 11.4 & Kilpimaa et al. 2014 \\
\hline & Chemically & & $9.14-27.55$ & Demiral and \\
\hline
\end{tabular}




\begin{tabular}{|c|c|c|c|c|}
\hline & modified sugar beet & \multirow{5}{*}{63} & & Gündüzoğlu, 2010 \\
\hline & $\begin{array}{l}\mathrm{Zr}(\mathrm{IV}) \text {-loaded sugar } \\
\text { beet pulp }\end{array}$ & & & Hassan et al. 2010 \\
\hline & $\begin{array}{l}\text { Sepiolite activated } \\
\text { by } \mathrm{HCl}\end{array}$ & & 38.16 & $\begin{array}{l}\text { Öztürk and Bekta, } \\
2004\end{array}$ \\
\hline & $\begin{array}{l}\text { Impregnated almond } \\
\text { shell activated } \\
\text { carbon }\end{array}$ & & $16-17$ & Rezaee et al. 2008 \\
\hline & $\begin{array}{l}\mathrm{ZnCl}_{2} \text { treated } \\
\text { coconut granular } \\
\text { activated carbon }\end{array}$ & & 10.2 & $\begin{array}{l}\text { Bhatnagar et al. } \\
2008\end{array}$ \\
\hline \multirow[t]{6}{*}{ Iron (II) } & $\begin{array}{l}\text { Chemically } \\
\text { activated carbon } \\
\text { residue }\end{array}$ & 20.5 & 21.4 & Runtti et al. 2014 \\
\hline & Carbon residue & 24.1 & 25.4 & Runtti et al. 2014 \\
\hline & $\begin{array}{l}\text { Commercial } \\
\text { activated carbon }\end{array}$ & 13.9 & 12.1 & Runtti et al. 2014 \\
\hline & Cow bone charcoal & - & 31.43 & Moreno et al. 2010 \\
\hline & $\begin{array}{l}\text { Commercial } \\
\text { activated carbon }\end{array}$ & - & 31 & Kouakou et al. 2013 \\
\hline & Hazelnut hull & - & 13.59 & Sheibani et al. 2012 \\
\hline \multirow[t]{13}{*}{ Copper(II) } & $\begin{array}{l}\text { Chemically } \\
\text { activated carbon } \\
\text { residue }\end{array}$ & 23.1 & 23.3 & Runtti et al. 2014 \\
\hline & Carbon residue & 11.1 & 10.1 & Runtti et al. 2014 \\
\hline & $\begin{array}{l}\text { Commercial } \\
\text { activated carbon }\end{array}$ & 5.1 & 4.4 & Runtti et al. 2014 \\
\hline & Granular biomass & 55.0 & - & $\begin{array}{l}\text { Hawari and } \\
\text { Mulligan, } 2006\end{array}$ \\
\hline & Activated slag & - & 30.0 & Gupta 1998 \\
\hline & Activated carbon & - & $18.1-22.0$ & $\begin{array}{l}\text { El-Ashtoukhy et al. } \\
2008\end{array}$ \\
\hline & $\begin{array}{l}\text { produced from } \\
\text { pomegranate peel }\end{array}$ & & & \\
\hline & Coal fly ash pellets & - & 20.9 & $\begin{array}{l}\text { Papandreou et al. } \\
2007\end{array}$ \\
\hline & Red mud & - & 19.7 & Lopez et al. 1998 \\
\hline & Na-Bentonite & & 17.9 & Liu et al. 2010 \\
\hline & Rubber wood & - & 5.7 & $\begin{array}{l}\text { Kalavathy et al. } \\
2005\end{array}$ \\
\hline & $\begin{array}{l}\text { sawdust activated } \\
\text { carbon }\end{array}$ & & & \\
\hline & Bagasse fly ash & - & 2.3 & Gupta and Ali, 2000 \\
\hline
\end{tabular}

Manuscript accepted for publication in: "Waste Biomass Management - A Holistic Approach (Eds. L. 


\begin{tabular}{|c|c|c|c|c|}
\hline & Olive stone waste & - & 1.87 & Fiol et al. 2006 \\
\hline \multirow[t]{13}{*}{ Nickel (II) } & Carbon residue & 5.6 & 5.7 & Runtti et al. 2014 \\
\hline & $\begin{array}{l}\text { Chemically } \\
\text { activated carbon } \\
\text { residue }\end{array}$ & 18.2 & 62.9 & Runtti et al. 2014 \\
\hline & $\begin{array}{l}\text { Irradiation-grafted } \\
\text { activated carbon }\end{array}$ & - & 55.7 & $\begin{array}{l}\text { Ewecharoen et al. } \\
2009\end{array}$ \\
\hline & Activated slag & - & 29.4 & Gupta 1998 \\
\hline & Granular biomass & 26.0 & - & $\begin{array}{l}\text { Hawari and } \\
\text { Mulligan, } 2006\end{array}$ \\
\hline & $\begin{array}{l}\text { Activated carbon } \\
\text { from }\end{array}$ & - & 16.9 & $\begin{array}{l}\text { Kalavathy et al. } \\
2010\end{array}$ \\
\hline & heveabrasiliensis & & & \\
\hline & $\begin{array}{l}\text { Commercial } \\
\text { activated carbon }\end{array}$ & 2.9 & 3.1 & Runtti et al. 2014 \\
\hline & Coir pith waste & - & 16.0 & Parab et al. 2006 \\
\hline & Na-bentonite & - & 14.0 & Liu et al. 2010 \\
\hline & $\begin{array}{l}\text { Activated carbon } \\
\text { prepared from } \\
\text { almond husk }\end{array}$ & - & $30.8-37.2$ & Hasar 2003 \\
\hline & Red mud & - & 11.0 & Lopez et al. 1998 \\
\hline & Olive stone waste & - & 2.3 & Fiol et al. 2006 \\
\hline
\end{tabular}

\section{Novel utilization applications for activated carbon}

Utilization applications of thermochemically produced carbon have been studied widely, and several potential applications have been reported in the literature. In this chapter, some utilization applications for activated carbon have been presented. Utilization applications as adsorbents are discussed in Chapter 5.

\subsection{Activated carbon in catalytic applications}

In the production process of a heterogeneous catalyst, active material is added to the surface of the support material. The support material should have specific properties, such as a large surface area. Activated carbons possess a number of properties making them very suitable support materials for heterogeneous catalysts. Carbons have good chemical stability under both acidic and alkaline conditions but also good mechanical stability. The large surface areas and the porosity make carbons ideal supports. The recovery of active metals is rather easy, because the carbon support can be removed by burning the coal and recovering the metal, a property that is most important when using rare and expensive metals as catalysts. The surface properties of

Manuscript accepted for publication in: "Waste Biomass Management - A Holistic Approach (Eds. L.

Singh and V.C. Kalia), Springer International Publishing, 2017. 
activated carbons can easily be modified by adding different functional groups. Activated carbon has been used as a catalyst support, for example, in the Fischer-Tropsch production of biodiesel starting from synthesis gas using cobalt as the active metal. (Tingjun and $\mathrm{Li}, 2015$ )

Another type of biodiesel produced by the transmetylation of fatty acids can be catalyzed by activated carbon supported catalysts (Konwar et al. 2014). The activated carbon itself can in some applications act as a catalyst. Actually, it has been used as a catalyst for the hydrolysis of cellulose in a mechano-catalytic application using ball-mill grinding. (Yabushita et al. 2014)

Activated carbon has been used as a support material in some catalytic processes (Lam and Luong, 2014):

- Hydrogenation of nitro aromatics on Pt-V/AC

- Reductive alkylation with $\mathrm{Pt} / \mathrm{C}$ (fine and specialty chemicals)

- Hydrogenation of dinitrotoluene to toluenediamine on Pd/carbon black

- Butanediol synthesis (hydrogenation of maleic acid) on Pd-Ag-Re/AC

- Terephthalic acid purification on Pt/AC

\subsection{Activated carbon as precursor for graphene in electrochemical applications}

One of the most recent discoveries regarding the use of biomass-based carbon is to produce graphene like nanosheets. Studies by Shams et al. (2015) show that it is possible to obtain few layer graphene (FLG) from biomass. From the mechanical and electrical point of view, the potential properties of graphene are well known. (Al-Saleh 2015) Specific applications in that research area are made, for example, in the use of manganese dioxide nanoplates which are anchored to the biomass-derived cross-linked carbon nanosheets for high-performance asymmetric supercapacitors ( $\mathrm{Li}$ et al. 2015). These supercapacitors showed impressive electrical performance because to the specific properties of graphene, such as high specific surface and conductivity.

The synthesis of porous graphene and activated carbon composite have been studied. In the studies of Zheng et al. (2014), the high packing density and a large specific surface area for supercapacitor electrode material have been used. (Zheng et al. 2014) with promising results. Particularly, the interest of researchers is to develop carbon as a precursor for graphene production from different biomass matrices. It is already known that different biomasses can generate carbons with different properties. For instance, pomelo peels carbon was used as an anode for lithium-based batteries (Sun et al. 2013). The use of biomass-derived material in the battery industry is still under investigation, and according to Zhang et al. (2015), biomass-based graphene could bring an almost totally renewable material (separator, binder and electrode) to battery production. This possibility of using porous activated carbon from biomass to the production of graphene and then to electrochemistry is still at a basic research level, and further applications have to be made and studies done. (Konwaret al. 2014)

Manuscript accepted for publication in: "Waste Biomass Management - A Holistic Approach (Eds. L. Singh and V.C. Kalia), Springer International Publishing, 2017. 


\subsection{Other utilization applications}

Biomass-based dry pyrolysis carbon or HTC-carbon have been used in addition to the applications mentioned earlier, for example, soil improvement, adsorption in the purification of gases, electronic applications, catalyst support material for producing sustainable catalysts, novel anode material in production of batteries, a bio-based reducer in the steelmaking industries and an environmental application to reduce carbon dioxide. The utilization of an adsorbent for removing impurities in an aqueous solution has been presented in Chapter 5. (Cakan et al. 2008; Makowski et al. 2008; Sevilla et al. 2011; Sevilla and Fuertes, 2011; Suopajärvi et al. 2014) In Table 8, some utilization applications based on literature and production conditions for the utilized materials are presented.

Table 8.Utilization applications for dry pyrolysis and HTC products.

\begin{tabular}{|c|c|c|c|c|}
\hline Raw material & Carbonization & Activation & $\begin{array}{l}\text { Utilization } \\
\text { application }\end{array}$ & Reference \\
\hline $\begin{array}{l}\alpha \text {-D-glucose, potato } \\
\text { starch, cellulose, } \\
\text { saw dust from } \\
\text { eucalyptus, furfural }\end{array}$ & $\begin{array}{l}\mathrm{HTC}\left(230{ }^{\circ} \mathrm{C}, 250\right. \\
\left.{ }^{\circ} \mathrm{C}\right)\end{array}$ & $\begin{array}{l}\text { Chemical }(\mathrm{KOH} \text {, } \\
\left.600-800{ }^{\circ} \mathrm{C}\right)\end{array}$ & Hydrogen storage & Sevilla et al. 2011 \\
\hline $\begin{array}{l}\text { Glucose }+ \text { Si- } \\
\text { nanoparticles }\end{array}$ & $\begin{array}{l}\text { HTC \& pyrolysis } \\
\left(900^{\circ} \mathrm{C}\right)\end{array}$ & No activation & $\begin{array}{l}\mathrm{C} / \mathrm{Si}- \\
\text { nanocomposites as } \\
\text { anode material for } \\
\text { lithium ion batteris }\end{array}$ & Cakan et al. 2008 \\
\hline Furfural + palladium & $\mathrm{HTC}\left(190^{\circ} \mathrm{C}\right)$ & No activation & $\begin{array}{l}\text { As Pd-catalyst } \\
\text { support in selective } \\
\text { hydrogenation to } \\
\text { cyclohexanone }\end{array}$ & $\begin{array}{l}\text { Makowski et al. } \\
2008\end{array}$ \\
\hline $\begin{array}{l}\text { Starch,cellulose, } \\
\text { saw dust }\end{array}$ & $\mathrm{HTC}\left(230-250{ }^{\circ} \mathrm{C}\right)$ & $\begin{array}{l}\text { Chemical }(\mathrm{KOH} \text {, } \\
\left.600-800{ }^{\circ} \mathrm{C}\right)\end{array}$ & $\begin{array}{l}\text { Adsorption of } \\
\text { carbon dioxide }\end{array}$ & $\begin{array}{l}\text { Sevilla and Fuertes, } \\
2011\end{array}$ \\
\hline
\end{tabular}

\section{Conclusions}

Biomass can be used as a precursor in activated carbon production. Biomass carbonization can be done by using thermochemical or hydrothermal treatments. After the carbonization step, activation can be performed physically or chemically. Biomass-based carbon can also be produced from carbonaceous waste materials. In this chapter, carbon residue from the wood gasification process was used as a raw material for activated carbon production, and it was presented as a case study. In chemical activation studies, the highest specific surface area for carbon residue was obtained using $\mathrm{ZnCl}_{2}$ as a chemical activating agent. In the physical activation procedure, the highest surface area was obtained using carbon dioxide as a physical activating agent. The widely used application for activated carbon is use as an adsorbent for the purification of gases and liquids. In the case study, physically and chemically activated carbon residue was used in the removal of phosphates, nitrates, iron(II), copper(II) and nickel(II) in wastewater treatment. Based on the results presented in the case study, activated carbon residue had a notably higher adsorption capacity compared with commercial activated carbon in the case of phosphate and heavy metal removal. Adsorption capacity is also substantially better for activated carbon residue compared with carbon residue, and therefore, the adsorption capacity Manuscript accepted for publication in: "Waste Biomass Management - A Holistic Approach (Eds. L. Singh and V.C. Kalia), Springer International Publishing, 2017. 
can clearly be enhanced by activation. The use of gasification carbon residue is not only an effective and inexpensive adsorbent, but also it has the potential to significantly reduce waste streams. Other potential utilization applications for activated carbon are, for example, use as a catalyst support and as a precursor in graphene production in battery production.

\section{Opinion}

The carbonization of biomass and the physical and/or chemical activation of carbon have been considered. The properties of obtained activated carbon were considered from an adsorption viewpoint. In addition to adsorption, other applications for carbon are available. It can be used as a catalyst support, as a carbon dioxide storage material and as an energy storage material in lithium ion batteries, for example.

\section{Acknowledgements}

The authors wish to thank the EU Interreg Nord program within the project no 304-8455-10 (HighBio2- Biomass to fuels and chemicals) and accompanying companies for their financial and technical support. The authors also thank project SULKA (A32164, 524/2012) and Maa- ja vesitekniikan tuki ry. D.B. acknowledges the Central Ostrobothnia Regional Fund for its personal grant. 
Ahmadpour A, Do D.D (1996) The preparation of active carbons from coal by chemical and physical activation. Carbon 34: 471-479. doi:10.1016/0008-6223(95)00204-9

Ahmadpour A, Do D.D (1997) The preparation of activated carbon from macadamia nutshell by chemical activation. Carbon 35: 1723-1732. doi:10.1016/S0008-6223(97)00127-9

Al-Saleh M.H (2015) Electrical and mechanical properties of graphene/carbon nanotube hybrid $\begin{array}{llll}\text { nanocomposites. } & \text { Synthetic } & \text { 41-46. }\end{array}$ doi:http://dx.doi.org/10.1016/j.synthmet.2015.06.023

Antal M.J, Grønli M (2003) The art, science, and technology of charcoal production. IndEngChem Res 42: 1619-1640. doi: 10.1021/ie0207919

Antal M.J, Allen S G, Dai X, Shimizu B, Tam M S, Grønli M (2000) Attainment of the theoretical yield of carbon from biomass. Ind Eng Chem Res 39: 4024-4031.doi: 10.1021/ie000511u

Avom J, KetchaMbadcam J, Noubactep C, Germain P (1997) Adsorption of methylene blue from an aqueous solution on to activated carbons from palm-tree cobs. Carbon 35: 365369. doi:10.1016/S0008-6223(96)00158-3

Bansal R.C, Meenakshi G (2005) Activated carbon adsorption. Boca Raton: Taylor \& Francis, $495 \mathrm{p}$.

Bart H-J, von Gemmingen U (2005) Ullmann's Encyclopedia of Industrial Chemistry Adsorption. Weinheim: Wiley-VCH VerlagGmbH\&Co, pp. 549-1620.

Bergna D, Romar H, Tuomikoski S, Lassi U (2016) A demineralization process for lower ash content in activated carbons, manuscript (unpublished data).

Bhatnagar A, Kumar E, Sillanpää M (2010a) Nitrate removal from water by nano-alumina: Characterization and sorption studies. Chem Eng J 163: 317-323. doi:10.1016/j.cej.2010.08.008

Bhatnagar A, Minocha A.K, Sillanpää M (2010b) Adsorptive removal of cobalt from aqueous solution by utilizing lemon peel as biosorbent. Biochem Eng J 48(2): 181-186. doi:10.1016/j.bej.2009.10.005

Bhatnagar A, Ji M, Choi Y-H, Jung W, Lee S-H, Kim S-J, Lee G, Suk H, Kim H-S, Min B, Kim S-H, Jeon B-H, Kang J-W (2008) Removal of nitrate from water by adsorption onto zinc chloride treated activated carbon. Sep Sci Technol 43: 886-907. doi:10.1080/01496390701787461

Borggaard O.K, Raben-Lange B, Gimsing A.L, Strobel B.W (2005) Influence of humic substances on phosphate adsorption by aluminium and iron oxides. Geoderma 127: 270279.doi:10.1016/j.geoderma.2004.12.011

Brewer C.E (2012) Biochar Characterization and Engineering, Dissertation, Iowa State University, $182 \mathrm{p}$.

Bridgwater A.V, Peacocke G.V.C (2000) Fast pyrolysis processes for biomass. Renew Sustain Energy Rev 4: 1-73.doi:10.1016/S1364-0321(99)00007-6

Bridgwater A.V (1999) Principles and practice of biomass fast pyrolysis processes for liquids. J Anal Appl Pyrolysis 51: 3-22. doi: 10.1016/S0165-2370(99)00005-4

Cakan R, Titirici M-M, Antinietti M, Cui G, Maier J, Hu Y-S (2008) Hydrothermal carbon spheres containing silicon nanoparticles: synthesis and lithium storage performance. Chem commun 3759-3761. doi: 10.1039/B805671B

Chang C-F, Chang C-Y \& Tsai W-T (2000) Effects of burn-off and activation temperature on preparation of activated carbon from corn cob agrowaste by $\mathrm{CO}_{2}$ and steam. J Colloid Int Sci 232(1): 45-49. doi:10.1006/jcis.2000.7171

Manuscript accepted for publication in: "Waste Biomass Management - A Holistic Approach (Eds. L.

Singh and V.C. Kalia), Springer International Publishing, 2017. 
Chun Y.N, Lim M.S, Yoshikawa K (2012) Characteristics of the product from steam activation of sewage sludge. J Ind Eng Chem 18(2): 839-847. doi:http://dx.doi.org/10.1016/j.jiec.2011.11.144

Council Directive (1999) 1999/31/EC Council Directive on the Landfill of Waste, http://eurlex.europa.eu/legal-content/EN/TXT/?uri=CELEX:31999L0031, accessed in 12.11.2015.

Demiral H, Gündüzoğlu G (2010) Removal of nitrate from aqueous solutions by activated carbon prepared from sugar beet bagasse. Bioresour Technol 101: 16751680.doi:10.1016/j.biortech.2009.09.087

El-Ashtoukhy E-S.Z, Amin N.K, Abdelwahab O (2008) Removal of lead (II) and copper (II) from aqueous solution using pomegranate peel as a new adsorbent. Desalination 223, 162173. doi:10.1016/j.desal.2007.01.206

European council of chemical manufacturers' federations (1986) Test methods for activated carbon: http://www.cefic.org/Documents/Other/Test-method-for-Activated-Carbon_86.pdf Accessed 20.10.2015

Ewecharoen A, Thiravetyan P, Wendel E, Bertagnolli H (2009) Nickel adsorption by sodium polyacrylate-grafted activated carbon. J Hazard Mater 171: 335-339. doi: 10.1016/j.jhazmat.2009.06.008.

Fagernäs L, Kuoppala E, Ranta J, Arpiainen V, Tiilikkala K, Kemppainen R, Hagner M, Setälä H (2014) Hidaspyrolyysituotteiden hyödyntäminen ja tuotannon kannattavuus: Biohiili ja tisle Espoo, Finland, VTT publications 182. ISBN 978-951-38-8277-8

Fischer Z, Bieńkowski P (1999) Some remarks about the effect of smoke from charcoal kilns on soil degradation. Environ Monit Assess 58: 349-358.doi: 10.1023/A:1006058512644

Fiol N, Villaescusa I, Martínez M, Miralles N, Poch J, Serarols J (2006) Sorption of Pb(II), $\mathrm{Ni}(\mathrm{II}), \mathrm{Cu}(\mathrm{II})$ and $\mathrm{Cd}(\mathrm{II})$ from aqueous solution by olive stone waste. Sep Purif Technol 50: 132-140. doi:10.1016/j.seppur.2005.11.016

Franklin R E (1951) Crystallite growth in graphitizing and non-graphitizing carbons. Proceeding of the Royal Society of London 209:196-218.

Freundlich H.M.F (1906) Over the adsorption in solution. J Phys Chem 57: 385-470.

Fu K, Yue Q, Gao B, Sun Y, Zhu L (2013) Preparation, characterization and application of lignin-based activated carbon from black liquor lignin by steam activation. Chem Eng J 228: 1074-1082. doi:http://dx.doi.org/10.1016/j.cej.2013.05.028

Funke A, Ziegler F (2010) Hydrothermal carbonization of biomass: A summary and discussion of chemical mechanisms for process engineering. Biofuels Bioprod Biorefining 4: 160177.doi: $10.1002 / \mathrm{bbb} .198$

Government Decree (2013) 331/2013 Valtioneuvoston asetus kaatopaikoista (in Finnish), https://www.finlex.fi/fi/laki/alkup/2013/20130331, accessed in 23.10.2015.

Guo S, Peng J, Li W, Yang K, Zhang L, Zhang S, Xia H (2009) Effects of CO2activation on porous structures of coconut shell-based activated carbons. Appl Surf Sci 255(20): 84438449. doi:10.1016/j.apsusc.2009.05.150

Gupta V.K (1998) Equilibrium uptake, sorption dynamics, process optimization, and column operations for the removal of copper and nickel from aqueous solution and wastewater using activated slag, a low-cost adsorbent. Ind Eng Chem Res 37: 192-202. doi: 10.1021/ie9703898

Gupta V.K, Ali I (2000) Utilisation of bagasse fly ah (a sugar industry waste) for the removal of copper and zinc from wastewater. Sep Purif Technol 18: 131-140. doi:10.1016/S13835866(99)00058-1

Manuscript accepted for publication in: "Waste Biomass Management - A Holistic Approach (Eds. L.

Singh and V.C. Kalia), Springer International Publishing, 2017. 
Hasar H (2003) Adsorption of nickel(II) from aqueous solution onto activated carbon prepared from almond husk. J Hazard Mater B97: 49-57.doi:10.1016/S0304-3894(02)00237-6

Hassan M.L, Kassem N.F, El-Lader A.H.A (2010) Novel Zr( IV)/sugar beet pulp composite for removal of sulfate and nitrate anions. J Appl Polym Sci 117(4): 2205-2212. doi: 10.1002/app.32063

Hawari A.H, Mulligan C.N (2006) Biosorption of lead(II), cadmium(II), copper(II) and nickel(II) by anaerobic granular biomass. Bioresour Technol 97: 692-700. doi:10.1016/j.biortech.2005.03.033

Ho Y.S, McKay G (1999) Pseudo-second-order model for sorption processes. Process Biochem 34: 451-465.doi:10.1016/S0032-9592(98)00112-5

International Committee for Characterization and Terminology of Carbon (1982) First publication of 30 tentative definitions. Carbon 20(5): 445-449.

Ioannidou O, Zabaniotou A (2007) Agricultural residues as precursors for activated carbon production - A review. Renew and Sustain Energy Reviews 11: 1966-2005. doi:10.1016/j.rser.2006.03.013

IUPAC Commision on Colloid and Surface Chemistry Including Catalysis (1985) Reporting Physisorption Data fo Gas/Solid Systems with Special Reference to the Determination of Surface Area and Porosity. Pure Appl Chem 57: 603.

IUPAC Manual of Symbols and Terminology, Appendix 2, Pt.1 (1972) J Colloid Interface Chem Pure Appl Chem 31: 578.

Kalavathy M.H, Karthikeyan T, Rajgopal S, Miranda L.R (2005) Kinetic and isotherm studies of $\mathrm{Cu}(\mathrm{II})$ adsorption onto H3PO4- activated rubber wood sawdust. J Colloids InterfSci 292: 354-362. doi:10.1016/j.jcis.2005.05.087

Kalavathy H, Karthik B, Miranda L.R (2010) Removal and recovery of Ni and Zn from aqueous solution using activated carbon from Heveabrasiliensis: Batch and column studies, Colloids and Surfaces B: Biointerfaces 78: 291-302. doi:10.1016/j.colsurfb.2010.03.014

Karthikeyan K.G, Mandla A, Wang T.D, Kalbasi M (2004) Solution Chemistry Effects on Orthophosphate Adsorption by Cationized Solid Wood Residues. Environ Sci Technol. 38:904-911. doi:10.1021/es034819z

Kilpimaa S, Kuokkanen T, Lassi U (2011) Physical and chemical properties of wood ash from burning and gasification processes. The Journal of Solid Waste Technology and Management, Proceedings in ICSW 2011: 879-887

Kilpimaa S, Runtti H, Lassi U, Kuokkanen T (2012) Chemical activation of gasification carbon residue for phosphate removal. Porous Media and its applications in Science, Engineering and Industry, AIP Conference Proceedings 2012: 293-298.

Kilpimaa S, Kuokkanen T, Lassi U (2013) Characterization and Utilization Potential of Wood Ash from Combustion Process and Carbon Residue from Gasification Process. Bioresources 8: 1011-1027.

Kilpimaa S, Runtti H, Kangas T, Lassi U, Kuokkanen T (2014) Removal of phosphate and nitrate over a modified carbon residue from biomass gasification. Chem Eng Res Des 92: 1923-1933. doi:10.1016/j.cherd.2014.03.019

Kilpimaa S, Runtti H, Kangas T, Lassi U, Kuokkanen T (2015) Physical activation of carbon residue from biomass gasification: Novel sorbent for the removal of phosphates and nitrates from aqueous solution, $J$ Ind Eng Chem 21:1354-1364. doi:10.1016/j.jiec.2014.06.006

Manuscript accepted for publication in: "Waste Biomass Management - A Holistic Approach (Eds. L.

Singh and V.C. Kalia), Springer International Publishing, 2017. 
Konwar L.J, Boro J, Deka D (2014) Review on latest developments in biodiesel production using carbon-based catalysts. Renewable and Sustainable Energy Reviews 29: 546-64. doi:10.1016/j.rser.2013.09.003

Kouakou U, Ello A S, Yapo J A, Trokourey A (2013) Adsorption of iron and zinc on commercial activated carbon. J Environ Chem Ecotoxic 5:168-171.doi: 10.5897/JECE2013.0264

Lagergren S (1898) About the theory of so-called adsorption of soluble substances. K Svenska Vetenskapsakad Handl 24: 1-39.

Lam E, Luong J.H.T (2014) Carbon Materials as Catalyst Supports and Catalysts in the Transformation of Biomass to Fuels and Chemicals. ACS Catalysis 4: 3393-3410. doi: doi.org/10.1021/cs5008393

Langmuir I (1918) The adsorption of gases on plane surfaces of glass, mica and platinum. J Am ChemSoc 40: 1361-1403.

Libra J.A, Ro K.S, Kammann C, Funke A, Berge N.D, Neubauer Y, Titirici M-M, Fühner C, Bens O, Kern J (2011) Hydrothermal carbonization of biomass residuals: a comparative review of the chemistry, process and applications of wet and dry pyrolysis. Biofuels 2: 71106.doi: http://doi.org/10.4155/bfs.10.81

Li Y, Yu N, Yan P, Li Y, Zhou X, Chen S, Fan Z (2015) Fabrication of manganese dioxide nanoplates anchoring on biomass-derived cross-linked carbon nanosheets for highperformance asymmetric supercapacitors. J Power Sources 300:309-317. doi:http://dx.doi.org/10.1016/j.jpowsour.2015.09.077

Liu Z-R, Zhou S-Q (2010) Adsorption of copper and nickel on Na-bentonite. Process Saf Environ Prot 88: 62-66. doi:10.1016/j.psep.2009.09.001

Lopez E, Soto B, Arias M, Nun' ez A, Rubinos D, Barral M.T (1998) Adsorbent properties of red mud and its use for wastewater treatment. Water Res 32: 13141322.doi:10.1016/S0043-1354(97)00326-6

Lussier M.G, Shull J.C, Miller D J (1994) Activated carbon from cherry stoes. Carbon 32: $1493-$ 1498.doi:10.1016/0008-6223(94)90144-9

Makowski P, Cakan R D, Antonietti M, Goettmann F, Titirici M-M (2008) Selective partial hydrogenation of hydroxy aromatic derivatives with palladium nanoparticles supported on hydrophilic carbon. Chem Commun 8: 999-1001.doi: 10.1039/B717928F

Marsh H, Rodríquez-Reinoso F (2006) Activated carbon. Amsterdam: Elsevier, 536 p.

Martínez M.L, Torres M.M, Guzmán C.A, Maestri D.M (2006) Preparation and characteristics of activated carbon from olive stones and walnut shells. Ind Crops and Prod 23: 23-28. doi:10.1016/j.indcrop.2005.03.001

Mezenner N.Y, Bensmaili A (2009) Kinetics and thermodynamic study of phosphate adsorption on iron hydroxide-eggshell waste. Chem Eng J 147: 87-96. doi:10.1016/j.cej.2008.06.024

Moreno J.C, Gómez R, Giraldo L (2010) Removal of Mn, Fe, Ni and Cu Ions from Wastewater Using Cow Bone Charcoal. Materials 3: 452-466.doi:10.3390/ma3010452

Moreno-Castilla C (2004) Adsorption of organic molecules from aqueous solutions on carbon materials. Carbon 42: 83-94. doi:10.1016/j.carbon.2003.09.022

Nabais J.V, Carrott P, Ribeiro Carrott M.M, Luz V, Ortiz A.L (2008) Influence of preparation conditions in the textural and chemical properties of activated carbons from a novel biomass precursor: the coffee endocarp. Bioresour Technol 99: 7224-7231.doi: 10.1016/j.biortech.2007.12.068

Manuscript accepted for publication in: "Waste Biomass Management - A Holistic Approach (Eds. L.

Singh and V.C. Kalia), Springer International Publishing, 2017. 
Namasivayam C, Sangeetha D (2008) Application of coconut coir pith for the removal of sulfate and other anions from water. Desalination 219: 1-13.doi:10.1016/j.desal.2007.03.008

Papandreou A, Stournaras C.J, Panias D (2007) Copper and cadmium adsorption on pellets made from fired coal fly ash. J Hazard Mater 148: 538-547. doi:10.1016/j.jhazmat.2007.03.020

Parab H, Joshi S, Shenoy N, Lali A, Sarma U.S, Sudersanan M (2006) Determination of kinetic and equilibrium parameters of the batch adsorption of $\mathrm{Co}(\mathrm{II}), \mathrm{Cr}(\mathrm{III})$ and $\mathrm{Ni}(\mathrm{II})$ onto coir pith. Process Biochem 41: 609-615. doi:10.1016/j.procbio.2005.08.006

Ragan S, Megonnell N (2011) Activated carbon from renewable resources - Lignin. Cellulose Chem. Technol. 45: 527-531

Ramke H-G, Blöhse D, Lehmann H -J, Fettig J (2009) Hydrothermal Carbonization of Organic Waste. In: Cossu R, Diaz L F, Stegmann R (eds), Sardinia 2009: Twelfth International Waste Management and Landfill Symposium, Sardinia, Italy, 05-09 October 2009, Proceedings, CISA Publisher

Rezaee A, Godini H, Dehestani S, Khavanin A (2008) Application of impregnate almond shell activated carbon b y zinc and zinc sulfate for nitrate removal from water. Iran J Environ Health Sci Eng 5: 125-130.

Repo E, Petrus R, Sillanpää M, Warchoł J.K (2011) Equilibrium studies on the adsorption of $\mathrm{Co}(\mathrm{II})$ and $\mathrm{Ni}(\mathrm{II})$ by modified silica gels: One-component and binary systems. Chem Eng J 172:376-385. doi:http://dx.doi.org.pc124152.oulu.fi:8080/10.1016/j.cej.2011.06.019

Repo E, Kurniawan T.A, Warchol J.K, Sillanpää M.E.T (2009) Removal of Co(II) and Ni(II) ions from contaminated water using silica gel functionalized with EDTA and/or DTPA as chelating agents. J Hazard Mater 171: 1071-1080. doi:http://dx.doi.org.pc124152.oulu.fi:8080/10.1016/j.jhazmat.2009.06.111

Rodríquez-Reinoso F, Molina-Sabio M (1998) Textural and chemical characterization of mocroporous carbons. Advances in Colloid and Interface Science 6-77: 271294.doi:10.1016/S0001-8686(98)00049-9

Roosta M, Ghaedi M, Daneshfar A, Sahraei R, Asghari A (2014a) Optimization of the ultrasonic assisted removal of methylene blue by gold nanoparticles loaded on activated carbon using experimental design methodology. Ultrason Sonochem 21(1): 242-252.doi: 10.1016/j.ultsonch.2013.05.014

Roosta M, Ghaedi M, Daneshfar A, Sahraei R (2014b) Experimental design based response surface methodology optimization of ultrasonic assisted adsorption of safaranin $O$ by tin sulfide nanoparticle loaded on activated carbon. Spectrochimica Acta Part A: Molecular and Biomolecular Spectrosc 122: 223-231.

Roosta M, Ghaedi M, Shokri N, Daneshfar A, Sahraei R, Asghari A (2014c) Optimization of the combined ultrasonic assisted/adsorption methods for the removal of malachite green by gold nanoparticles loaded on activated carbon: Experimental design. Spectrochimica Acta Part A: Molecular and Biomolecular Spectrosc 118: 55-65.doi: 10.1016/j.saa.2013.08.082

Runtti H, Tuomikoski S, Kangas T, Lassi U, Kuokkanen T, Rämö J (2014) Chemically activated carbon residue from biomass gasification as a sorbent for iron(II), copper(II) and nickel(II) ions, J Water Process Eng 4: 12-24.doi:10.1016/j.jwpe.2014.08.009

Ruthven D.M (1984) Principles of adsorption and adsorption processes. New York: Wiley, 433 p.

Sadaka S, Negi S (2009) Improvements of biomass physical and thermochemical characteristics via torrefaction process. Environ Prog Sustain Energy 28: 427-434.doi: 10.1002/ep.10392

Manuscript accepted for publication in: "Waste Biomass Management - A Holistic Approach (Eds. L.

Singh and V.C. Kalia), Springer International Publishing, 2017. 
Sevilla M, Maciá-Agulló J.A, Fuertes A.B (2011) Hydrothermal carbonization of biomass as a route for the sequestration of $\mathrm{CO} 2$ : Chemical and structural properties of the carbonized products. Biomass Bioenergy 35: 3152-3159.doi: 10.1016/j.biombioe.2011.04.032

Sevilla M, Fuertes A.B (2011) Sustainable porous carbons with a superior performance for CO2 capture. Energy Environ 4: 1765-1771. doi: 10.1039/C0EE00784F

Shams S.S, Zhang L.S, Hu R, Zhang R, Zhu J (2015) Synthesis of graphene from biomass: A green chemistry approach. Materials Letters, 161: 476-479. doi:http://dx.doi.org/10.1016/j.matlet.2015.09.022

Sheibani A, Shishehbor M.R, Alaei H (2012) Removal of Fe(III) ions from aqueous solutionbyhazelnut hull as an adsorbent.Int J IndChem 3: 1-4.doi:10.1186/2228-5547-3-4

Srinivasakannan C, Zailani A.B.M (2004) Production of activated carbon from rubber wood sawdust. Biomass Bioenergy 27: 89-96. doi:10.1016/j.biombioe.2003.11.002

Sun X, Wang X, Feng N, Qiao L, Li X, He D (2013) A new carbonaceous material derived from biomass source peels as an improved anode for lithium ion batteries. J Anal Appl Pyrolysis, 100: 181-185. doi:http://dx.doi.org/10.1016/j.jaap.2012.12.016

Suopajärvi H, Pongrácz E, Fabritius T (2014) Bioreducer use in Finnish blast furnace ironmaking - Analysis of $\mathrm{CO} 2$ emission reduction potential and mitigation cost. Appl Energy 124: 82-93. doi:10.1016/j.apenergy.2014.03.008

Tan I.A.W, Ahmad A.L, Hameed B.H (2008) Preparation of activated carbon fromcoconut husk: Optimization study on removal of 2,4,6-trichlorophenol using response surface methodology. J Hazard Mater 153: 709-717. doi:10.1016/j.jhazmat.2007.09.014

Teker M, Saltabas Ö, İmamoğlu M (1997) Adsorption of cobalt by activated carbon from the rice hulls. J Environ Sci Health 32: 2077-2086.doi:10.1080/10934529709376668

Temkin M.J, Pyzhev V (1940) Recent modifications to Langmuir isotherms. Acta Physiochim URSS 12: 217-222.

Tingjun F, Li Z (2015) Review of recent development in Co-based catalysts supported on carbon materials for Fischer-Tropsch synthesis. Chemical Engineering Science 135: 3-20. doi:10.1016/j.ces.2015.03.007

Tuomikoski S (2014) Utilisation of gasification carbon residues - Activation, characterisation and use as an adsorbent, D.Sc. thesis, University of Oulu, Department of Physics and Chemistry.

Wu D, Zhang B, Li C, Zhang Z, Kong H (2006) Simultaneous removal of ammonium and phosphate by zeolite synthesized from fl y ash as influenced by salt treatment. J Colloid IntSci 304: 300-360. doi:10.1016/j.jcis.2006.09.011

Yabushita M, Kobayashi H, Haraa K, Fukuoka A (2014) Quantitative evaluation of ball-milling effects on the hydrolysis of cellulose catalysed by activated carbon. Catalysis Science \& Technology 4: 2312.doi: 10.1039/C4CY00175C

Zeng L, Li X, Liu J (2004) Adsorptive removal of phosphate from aqueous solutions using iron oxide tailings. Water Res 38: 1318-1326.doi:10.1016/j.watres.2003.12.009

Zhang L, Liu Z, Cui G, Chen L (2015) Biomass-derived materials for electrochemical energy storages. Progress in Polymer Science, 43: 136164.doi:http://dx.doi.org/10.1016/j.progpolymsci.2014.09.003

Zheng H, Liu D, Zheng Y, Liang S, Liu Z (2009) Sorption isotherm and kinetic modeling of aniline on Cr-bentonite. J Hazard Mater 167: 141-147.

Zheng C, Zhou X, Cao H, Wang G, Liu Z (2014) Synthesis of porous graphene/activated carbon composite with high packing density and large specific surface area for supercapacitor

Manuscript accepted for publication in: "Waste Biomass Management - A Holistic Approach (Eds. L.

Singh and V.C. Kalia), Springer International Publishing, 2017. 
$\begin{array}{lllll}\text { electrode material. J } & \text { 290-296. }\end{array}$ doi:http://dx.doi.org/10.1016/j.jpowsour.2014.01.056

Öztürk N, Bekta T E (2004) Nitrate removal from aqueous solution by adsorption onto various materials. J Hazard Mater 112: 155-162.doi:10.1016/j.jhazmat.2004.05.001 